\title{
Clientelism as civil society? Unpacking the relationship between clientelism and democracy at the local level in South Africa
}

\author{
Fiona Anciano
}

\begin{abstract}
This article, building on analyses from the global south, attempts to reframe democratic expectations by considering where previously maligned practices such as clientelism may hold moments of democracy. It does so by comparing the theory of civil society with that of clientelism, and its African counterpart neo-patrimonialism. It argues that clientelism as civil society may fulfil democratic tasks such as holding the (local) state accountable, strengthening civil and political liberties and providing channels of access for previously marginalised groups. Clientelism is not necessarily a reflection of imposed power relations but, at times, can demonstrate a conscious political strategy, to generate development, on the part of its protagonists.
\end{abstract}

Clientelism (as a process) and civil society (as an actor) are two concepts that are frequently referred to when looking at types of engagement, and those that mediate engagement, between state and society. The first has traditionally been vilified, the second valorised. This study is concerned with the nature of civil society and compares it to that of clientelism, arguing that in practice there are many similarities between the way in which civil society organisations engage political actors and the state, and the way in which clientelism operates. Drawing on research from the community of Hangberg in Hout Bay, South Africa, I will argue that the nature of civil society in a particular setting may be conditioned by the nature of the state as experienced at the local level. On the one hand, citizens ${ }^{1}$ may engage with a formalised, neoliberal state through mediators that can be likened to liberal democratic understandings of civil society organisations deepening democracy (see Gaventa, 2007). On the other, avenues to development are often opaque and clientelism and patronage commonplace; here the same civil society organisation can be understood as a broker facilitating loose networks of clients effectively engaging patrons in the form of both political party and the local or regional state.

If one organisation can be justifiably viewed from two perspectives, it raises the question of whether researchers should extend the same courtesy of investigating the relationship between clientelism and democracy that they do for the relationship between civil society and democracy. 
Drawing from empirical evidence this article argues that clientelism can, in certain contexts, be understood as a form of civil society activity and, as such, is not always wholly undemocratic. Ultimately clientelism as civil society may fulfil democratic tasks such as holding the (local) state accountable, strengthening civil and political liberties and providing channels of access for previously marginalised groups; equally, clientelism, as with civil society, may indeed weaken democratic norms. Both struggle to deal effectively with the democratic principle of equality. This paper builds on analysis from the global South that looks at existing practices of everyday engagement in informal locations and economies (Bayat, 1997; Chatterjee, 2004; Holston, 2008; Koelble and Lipuma, 2008; Piper and von Lieres, 2014). Frameworks derived from Western trajectories of state-society relations are often inadequate for describing and analysing the way in which citizens actually engage with the state on a regular basis in postcolonial states. As Koelble and Lipuma (2008: 8) explained, postcolonial states have a different socio-historical trajectory from their EuroAmerican counterparts and are thus 'not easily assimilated to a one model fits all developmentalism...these nations and peoples...may have to devise novel ways of attaining prosperity and substantive rights'. Euro-American frameworks tend, perhaps unintentionally, to vilify many everyday practices of citizen engagement. I attempt here to reframe democratic expectations in order to unpack where previously maligned practices such as clientelism may actually hold democratic moments. 'Moments of democracy' experienced through clientelism cannot be seen as a way of entrenching long term institutionalised norms of accountability; however, they offer, in spaces where residents often have little or no avenues of regular democratic expression, the opportunity to hold local leaders and political brokers accountable.

The nature of democracy and its trajectory are ongoing questions occupying discourse in South Africa. Currently there is a media focus on the notion of state capture (e.g. de Wet, 2016) which is often likened to the idea of corruption, or harmful clientelism writ large. This is not a new phenomenon in South Africa; during apartheid, political corruption and patronage was entrenched in domains of government activity. The extent to which a culture of secrecy and lack of accountability evolved within the swollen executive arm of government, and the extent to which this permeated every level of administration cannot be underestimated (Calland, 1998: 32). State capture occurs when rule-making processes and actors, such as executives, state ministries or the judiciary, are controlled to favour private interests (World Bank, 2000: xv) While state capture is, as with clientelism, conventionally framed negatively, several scholars investigating the practice reason (as is reflected in this paper) that it is not necessarily a reflection of a weak democracy. Van Holdt (2013), for example, argued that the interaction between democratic institutions and power relations (including the process of clientelism) within the elite, and between the elite and subalterns, produces particular forms of violence, but that this violence is not a reflection of a failed democracy, rather a reflection of power relations configured in such a way that violent practices are integral to them. For Chipkin (2016: 2), state capture (or corruption) is not simply a reflection of a dysfunctional public service, or an absence of ethical conduct, it is rather a reflection of different ideologies of the state; it reveals a different conception of virtue in public affairs. This echoes earlier work by African scholars such as Ekeh (1975) who 
argued that, on the back of a colonial history, there is a conception of the civic public realm (for example government departments) where it is acceptable to use personal networks for private gain from public resources. The pervasiveness of these practices and their more recent manifestation in South Africa, are most clearly seen through the activities of the ruling African National Congress (ANC) (Beresford, 2015; Lodge, 2014).

While these studies provide national level analysis, there are useful correlations in urban studies in South Africa. Studies by Bénit-Gbaffou (2011) and Dawson (2014) have shown how clientelism and patronage are used at the local level to distribute state resources, from food parcels to job opportunities. While challenging Weberian state principles, this form of clientelism can generate local and immediate accountability of politicians and is thus not anti-democratic per se, even if it does not allow for the challenge of broader policy directives. The (limited) agency of clients is also recognised, where clientelism is used as a deliberate political strategy and where clients are able to hold elites accountable (see also Beresford, 2015: 244). This paper builds on this analysis, using similar methodological processes to extend the investigation into the relationship between clientelism and democracy at the local level.

This article reports on case study research of the fishing village of Hangberg in Hout Bay, Cape Town. It draws on qualitative fieldwork, including interviews, focus groups and informal observation conducted between March 2015 and December 2016. Three categories of respondents were interviewed in order to triangulate data: city officials, leaders of local civil society organisations, and ordinary residents in Hangberg. Individual interviews were conducted with officials and political and civil society leaders, while focus groups were conducted with Hangberg residents. The study forms part of a larger research project in the suburb of Hout Bay, in which more than 60 interviews, five focus groups and 10 community meetings have been conducted or observed. 2 Where not individually attributed, general observations in the paper are based on this ongoing research. The site of Hangberg was chosen because it falls within a ward, City and Province run by the Democratic Alliance, the largest opposition party at a national level in South Africa. Research on clientelism and patronage in South Africa predominantly focuses on the ANC, as noted above. This choice of site thus provides for comparative analysis, investigating state-society relations that may be common across all political parties, rather than symptomatic of one.

\section{The story of Hangberg: state society relations in the battle for housing}

The village of Hangberg is situated on the extreme edge of the diverse suburb of Hout Bay, zoned for 'Coloureds' under the 1950 Group Areas Act.3 The area allocated for Hangberg residents may have beautiful views of the sea, but it is situated on a steep mountainside and occupies a very small portion of the larger Hout Bay valley (Greef, 2013). A key issue in Hangberg is land ownership and housing, with the strong perception expressed by residents that there is inadequate provision of housing by the state. This led to the growth of an informal settlement, after 1994, and the spread of backyard dwellings. While the informal settlement received rudimentary services in 2001 and 2004 from the City of Cape Town, 
residents have historically been unhappy about the level of services in the area. As the informal settlement grew, and facilities deteriorated, the community was prompted to engage the City about informal settlement upgrading (Fieuw, 2011). In March 2007 the City of Cape Town applied for the country's first in situ upgrade via the Upgrading of Informal Settlements Programme (USIP).

There was optimism that the USIP programme would be successful because it suits environments where there are high levels of community-initiated development and relatively closed, socially-bound communities with strong leadership and civil society structures that can navigate the complex negotiations required; dynamics which, superficially, were present in Hangberg (Fieuw, 2011). In fact, the Hout Bay Civic Association (HBCA) - a Hangberg based civil society organisation historically linked to the ANC - worked closely with an NGO (the Development Action Group to lobby for the USIP. In order to support the USIP a project steering committee was formed in Hangberg called the Hangberg in situ Development Association (HiDA), consisting of four steering members and representatives from every block. They were democratically elected to represent the community in matters pertaining to the upgrading project.

By October 2007 HiDA and the City of Cape Town had agreed on a moratorium on the construction of new (illegal) structures in Hangberg; and that if the moratorium was broken City law enforcement would be asked to intervene. The agreement also discussed the scope of the USIP, limiting the project to 302 housing opportunities in Hangberg. The City, however, did not set up any arrangement to monitor the moratorium and so HiDA was left with the difficult task of policing the agreement through negotiations with local residents. Furthermore, new power dynamics materialised between the qualifiers and non-qualifiers of the proposed development (Ehebrecht, 2014; Fieuw, 2011). There was a sense by some in Hangberg that leaders of HiDA were misappropriating funds. As a Khoi Chief resident in Hangberg explained, 'a lot of money never came forward and it disappeared'. Craig, a longstanding leader of a civil society organisation in Hangberg, described how 'leaders had access to opportunities...they sold the community for themselves'. There was, unsurprisingly (given the need for an expanding community to build new houses), continuing illegal construction of bungalows, and residents soon built new structures on the firebreak above Hangberg, breaking a key agreement in the moratorium (Fieuw, 2011).

Three years after the signing of the moratorium, housing concerns once again erupted. The previous mayor of Cape Town and Premier at that time of the Western Cape, Helen Zille, attempted to address the infringements of the 2007 agreement by holding a public meeting, which was ultimately unsuccessful. Following this she ordered the city police to dismantle 'unoccupied' structures on the firebreak. Residents were clear that these structures were in fact occupied and thus on 21 September 2010 there was a violent confrontation between police, representing the City, and residents, mainly in the informal settlement part of Hangberg, in what came to be known as the 'Battle for Hangberg'. The battle between police and residents waged for two days with numerous arrests and severe injuries, including 
permanent loss of sight, caused by rubber bullets, for several residents (Kaganof and Valley, 2010).

Notwithstanding the nationally televised 'Battle', the City was not deterred in its approach and later in the month applied for a court eviction order to dismantle a further 52 shacks on the fire-break. However, South African National Parks (SANParks) no longer supported the eviction order, allegedly due to political pressure from the (ANC) Minister of Environmental Affairs. This change of heart was seen as politically motivated and designed to tarnish the cityrun Democratic Alliance's reputation (South African Press Association, 2010). The court, with the backing of relevant parties, decided not to issue an eviction order, instead mandating the formation of a mediated forum to discuss the way forward in the upgrading project. Through this court order the Peace and Mediation Forum (PMF) was initiated. Over a period of seven weeks residents from three sectors in Hangberg (informal settlement, rental dwellers and ratepayers) elected 39 leaders. A core steering committee and representatives from every block were chosen. Craig, now a leader of the PMF, explained how some leaders of the HBCA were elected onto the PMF, while others resented the formation of the PMF and contested its legitimacy, distancing themselves from the PMF process.

Once representatives were elected it was possible for the PMF (representing the Hangberg community) SANParks, the Provincial Government and the City to sign a Peace and Mediation Accord. The Accord became an official order of the court in September 2011. According to the Mayor, De Lille:

The accord...will see those who live above the firebreak come down below the firebreak...Those who move beneath the firebreak will be encouraged to move into areas that we can provide services to...Still others will move into new housing opportunities once developed...The whole community...will especially receive the benefits of the City's departments of Economic Development, Social Development and Sports Departments as well as the Department of Human Settlements, to say nothing of general City services. De Lille (2011b)

Over time the PMF did work closely, although not always effectively, with the City and the Province to upgrade Hangberg. For example, City-owned rental units have been upgraded (according to one PMF leader at a cost of one million Rand each) and a new block of flats was built in 2016. Indeed, the Mayor asserted that the partnership with the PMF had resulted in positive strides being made towards developmental outcomes while striving towards the goal of 'inclusive collaboration' (De Lille, 2011a). Members of the PMF explained how, after 2013, the organisation has become more fractured as members disagreed over several issues, including negotiations with the City and differences of view with the Mayor and Premier. Certain members interviewed also felt that the PMF leadership became focused on meeting personal interests rather than supporting the wider community. The forum was, according to local activist Pastor Bill, reconstituted through new elections at the end of 2013, although it had a smaller leadership component. 
The formation of the PMF triggers interesting questions about the nature of statesociety engagement at the local level. Is the PMF a conventional civil society organisation or, given its close links to the Democratic Alliance and the City, and its role as the 'only legitimate' representative of the community, a clientelistic formation? In both incarnations how does it relate to democratisation? Before we can turn to this discussion it is useful to unpack the concepts of civil society and clientelism.

\section{What is civil society?}

Since its upsurge in popularity in the late 1980 s civil society has frequently been viewed as a panacea to deal with the democratic deficit facing both developed and developing countries. Scholars argue, for example, that a vibrant civil society is essential to building a strong democracy because it is in this realm that democratic citizenship is developed and the state held accountable (Chandhoke, 2001; Diamond 1994, 1999). The concept of civil society has a distinguished history, originating in ancient Rome and Athens and re-emerging in the 18th century. However, it was the developments of the late 1980s in Eastern Europe that spurred a contemporary reassessment of the usefulness of the concept; here it was used in the struggles of the democratic oppositions against authoritarian regimes. There is now an understanding that civil society is a 'space for action' that can be used to challenge the state and/or strengthen democracy (Pratt, 2003; Van Rooy, 1998).

This view comes from a liberal tradition of civil society theory, exemplified by Alexis de Tocqueville's idea of 'the immense assemblage of associations' transforming a mass of citizens into a body politic (Young, 1994: 35). For de Tocqueville, 'associations are established to promote public order, commerce, industry, morality, and religion; for there is no end which the human will, seconded by the collective exertions of the individual, despairs of attaining' (de Tocqueville, 1959). De Tocqueville further felt the state should be checked by the 'independent eye of society' (Kumar, 1993: 381). Thus, civil society should find the means to limit state power and hold it accountable. Later, liberals saw civil society as an active arena where individuals collectively organised themselves to limit the power of the state (Chandhoke, 1995). However liberals failed to theorise the problems in civil society itself. Gramsci, following Hegel and Marx applied himself to this task. Hegel viewed civil society as inherently conflictual and unstable because of the competitive interplay of private interests (Bratton, 1994). Gramsci, too, scrutinised the internal problems in civil society, noting that although it marked an historical advance and was the outcome of a 'civilizing process' it could be far from civilized (Shawstack Sassoon, 2000: 70). Most importantly, Gramsci believed that the ideas and values embodied in relations in civil society would no longer be used to justify existing hegemonic power structures, for where there is power there is resistance to it (Simon, 1991). Thus for Gramsci, 'Civil society was the ideological realm par excellence and potentially the source of either hegemonic or counter-hegemonic ideas' (Bratton, 1994: 55).

Civil society is thus a broad term understood in both normatively and empirically. Normatively, for example, it can be seen, as favoured by liberal democrats, as the good society, rooted in the Greek polis where all are free to speak their minds and have their voices 
heard, where civil society is the kind of society in which we want to live (Edwards, 2004). Empirically it can be seen as associational life, drawing from de Tocqueville's idea of a realm of associations which are part of society but distinct from state and markets. Both normatively and empirically, liberals and Marxists would argue it constitutes a public sphere, where a polity can deliberate openly and (particularly for liberals) democratically to reach a resolution of differences.

\section{What is clientelism?}

Clientelism as a concept is almost as difficult to define as civil society. Largely this is because it manifests in various forms and the negative values associated with it are increasingly being challenged. Earlier writing on clientelism frequently viewed the clientelistic relationship as one of domination and inequality, including different forms of social interaction such as exchange, conflict and prostitution. Clientelistic relations constituted a realm of submission; a pillar of oligarchic domination that reinforced and perpetuated the role of traditional political elites (Hagopian, cited in Auyero, 1999: 297). Focus has often been placed on how political parties use material incentives to win votes. However Fox (2012) explains that this is too exclusive a view because it does not take into account the various ways in which state actors use their control over access to public resources to manipulate citizens. Indeed, brokers need not always be politicians. The extent to which you can ascertain whether resource allocation is clientelistic is through the extent to which the process is transparent and whether citizens have access to effective channels of recourse if there is political abuse (Fox, 2012).

Clientelism can also be experienced in both individual and collective settings. Based on research in Brazil, Gay (1998: 14) argued that clientelism was increasingly a means by which to pursue the delivery of collective interests as opposed to individual goods. Political clients are therefore more likely to assume the form of organisations and communities that 'fashion relationships or reach understandings with politicians, public officials and administrations' (Gay 1998:14). Clientelism can display both hierarchical and relational elements as well as elements of collective organisation and identity. Lastly, levels and scale make a difference to how one assesses clientelism (Fox, 2012); at the local level an act can be experienced as clientelistic (such as the allocation of a housing unit), but at the macro (provincial or national) level it may be framed as developmental planning or simply democratic politics (for example, changing a housing policy to influence who decides on the allocation of housing units). It is how it is interpreted and enacted at the local level that can result in clientelism. The delivery of programme benefits can be controlled by partisan operatives in specific regions. In fact, the USIP is a national programme, which the meso (Provincial) and micro (City) levels of government decided to implement in Hangberg.

During the 1960 s and 1970 s clientelism was seen as an example of unaccomplished modernisation or a cultural trait typical of agrarian or so-called 'backward societies'. This changed to some extent in the 1980 os and 1990 s during which clientelism began to be seen not as a phenomenon that would disappear in the course of development, but rather as a mode of social exchange and political mobilisation identifiable in 'first' and 'second' world 
countries (de Sousa, 2008; Roniger, 2004). In the African context, the concept of clientelism relates closely to that of 'neo-patrimonialism'; a system where personal rule exists alongside legal-bureaucratic order (Lodge, 2014). Neo-patrimonialism has been used in a wide variety of contexts but is essentially seen as a combination of clientelistic practices and Weber's patrimonialism where, according to Medard (1982: 178), government powers and associated advantages are treated as private rights.

Clientelism, as with neo-patrimonialism, is frequently regarded as a threat to the foundations of democracy, leading to government capture by interest groups, damaging institutional performance of the state and undermining the idea of the public good. From this viewpoint clientelism goes against the institutionalisation of public accountability and mechanisms of administrative control. It can lead to the overemployment of underqualified personnel in public administration, biased processes of public works and overpricing, and private deals involving public resources (Roniger, 2004: 354). Clientelism (and concomitantly neo-patrimonialism) is thus 'almost universally described as an evil, largely responsible for the failure of democracy in Africa' (Bénit-Gbaffou, 2011: 456). It is viewed as replacing political accountability with a transaction, where citizens 'surrender their vote for the right price' (Kitschelt and Wilkinson, 2007: 2). Certainly, clientelism thrives in situations of inequality and poverty (Gay, 1998) and as such is poorly suited to challenging entrenched social or economic inequality and hegemonic positions of power. Clientelistic practices struggle to challenge existing power holders who can quickly remove their patronage. Furthermore, clientelism will struggle to challenge the neo-liberal logic of the state. Clientelism can lead to the subordination of the masses to political elites and limit the role of the clients in challenging power. It may also inhibit collective organisation and fragment the poor (Gay, 1998). Nonetheless there is a new wave of studies, particularly emanating from the global South, which look at the potential of clientelism to function effectively for resource distribution in democracies. Research on neo-patrimonialism (Pitcher et al., 2009) argues that the practice is not simply an anachronistic remnant but rather a form of authority that can function effectively in democratic settings; patrimonial leaders can be held accountable by the collective. This tension in the framing and practice of clientelism is investigated in this present paper, through an analysis of the PMF in Hangberg.

\section{Hangberg and the PMF: civil society or clientelism?}

Before turning to the question of how clientelism may relate to civil society, and indeed what similarities the concepts share in relation to democracy, it is useful to discuss whether the story of Hangberg is a story of clientelism or of civil society engagement; I argue that it can be read as both. The formation of the PMF could be regarded as the formation of a conventional civil society organisation. If one follows a definition of civil society that takes into account both liberal and Gramscian notions we can regard it in accordance with White's view that it is: '...an associational realm operating between the state and the family. Its organisations are self-ruling, able to both engage with, and challenge, the state. Members of society join civil society organisations voluntarily to protect or extend their interests' (White, 2008: 58). In the case of Hangberg the PMF could be viewed as a 
formally constituted association operating between the state and the family that engages with, and at times challenges, the state. Membership of the association is voluntary even if the forum is court ordered, and those who engage with the PMF do so to extend their interests. In this regard it plays a similar role to that of a trade union. It is a legislated requirement but membership is voluntary and its role does not preclude (invented) action from other civil society formations.

The PMF, however, is also engaged in clientelistic relations, both as client of the Democratic Alliance-run City, and at times patron to those seeking access to City services. According to a relatively recent PMF leader, Eunice, 'The Forum is actually the only recognized legal entity within the community that has a right to liaise with City, SANParks and Province. So whenever there jobs or anything that is coming out regarding the community, the Hangberg community only they have to speak to the PMF'. The head of Informal Settlement Upgrading for the City agrees that 'although there are a number of structures...we only work with the PMF'. The PMF performs the task of a broker: a political broker, in a clientelistic setting, can either 'obstruct or facilitate the flow of demands, favours, goods and services to or from some constituency' (cited in Auyero, 1999: 304). If the PMF behaves as the state wishes it will receive patronage, which its leaders can dispense to individual clients. In return the City will deliver, for example, housing. Clientelistic relationships can, however, include access to a range of opportunities beyond fixed resources, such as public employment (Fox, 2012).

The PMF could further be seen as clientelistic because its leaders are perceived by many to be biased in favour of the Democratic Alliance. According to Pastor Bill, 'There was a feeling that the forum was a vehicle for the DA' and an HBCA member explained that, '...more than $90 \%$ of the PMF belong to the DA...it's political'. In a focus group with young male residents in Hangberg they too stated that 'the DA and the PMF are the same, for other people they may look separate but we know they are one'; while another resident, who is still waiting to be given housing, felt that the allocation of the new flats was related to political party affiliation: 'those new flats...it's a DA story'. Not all respondents felt there was a strong political link with the Democratic Alliance; leaders of the PMF were emphatic that they were not simply party stooges, but that they needed to work with the DA because it is the ruling party in the City.

However, the PMF leaders, and others with whom they associated closely, are widely perceived in the community to allocate resources in a biased manner, based on their networks. As one resident of the Hangberg community described it, 'there [are] always projects coming up like for computer courses and you will only see the same people attending these and we know it's family because everyone knows each other... it's the same people year in, year out... they are the ones the information comes to, which they keep in the family'. Indeed, a previous member of the PMF had stopped working with them out of frustration that 'they work for themselves', deciding for rather than with the community about the allocation of resources. The youth focus group also stated that 'those people [PMF leaders] are naaiers...who just cater after themselves...the people here don't have jobs...we don't have jobs...but they look after themselves and their friends and family'. A 
perception that benefits in Hangberg are distributed according to family networks was also voiced by community leaders from the neighbouring Imizamo Yethu township in Hout Bay.

However, not all goods and services in Hangberg are allocated on a clientelistic basis. Access to the clinic or social grants, for example, is not partisan and not mediated by the PMF. While accepting that this does not nullify the practice of clientelism, clientelism, as Fox (2012) explained, can involve a mix of politicised resource allocation and rights-based, or entitlement-based, resource allocation. When examining the principles under which public goods are allocated, this is seldom done on a basis of only needs-based, bureaucratic criteria or political discretion. The functioning of the PMF is a good illustration of this mix; certainly aspects of the allocation and design of the housing project, for example, are needs-based, independent of political control - such as the upgrade of existing council flats which will continue to be occupied by longstanding residents, regardless of political affiliation. Yet there is little doubt the Democratic Alliance would value political benefit from a (hopefully) successful in-situ upgrade. Who allocates the new housing units, and to whom, is also highly contested and points to clientelistic relations. Some, including Pastor Bill, explained that they have been told the new flats are allocated by the City's Housing office situated in Hangberg, working from a database. Others, including PMF leader Craig, described how 'They don't know, they say the wanted us to give it, I said you want to tell me I must make a decision who must move into those houses....as a leader the people will say "you sorted your family out, you sorted your friends out". Your housing lists are $\mathrm{f}^{* * *}$....don't say community quickly spend this money because there is elections coming up'.

The fact that no one is clear about who allocates housing in Hangberg points to clientelism in the form of a lack of transparency in resource distribution. Certainly there are institutional channels available for recourse, if it is believed there is political abuse, but to access these channels requires resources, and often legal support, and this makes any such access difficult for many of the poorer residents in Hangberg. Ironically the PMF would theoretically be a channel residents could use to access institutional channels (and politicians) to contest the allocation of housing. Nonetheless, there is often likely to be a mix of clientelistic discretionary and rules-based allocation of resources. In terms of private goods, such as government housing, allocation would be clientelistic where discretionary criteria (potentially based on political affiliation) are used for allocation, whereas programmatic logic would be in play where allocation to families was based on objective indicators such as need or socio-economic status (Fox, 2012). In Hangberg, the allocation of housing appears to reflect this mix of clientelistic discretion and rules-based allocation.

Clientelism can also be a problem regarding symbolic resources and political 'credit' as much as it is over jobs, infrastructure and access to the state (Gay, 1998: 16). Indeed, for many of the leaders, particularly those elected in 2011, engaging in the PMF gave them a strong sense of legitimacy and importance in their community. Although clientelism is often essentially about 'reward at the ballot box' it can also be a popular political strategy (Gay, 1998: 14). On the surface the PMF is not directly a supporter of the Democratic Alliance, in 
contrast to the HBCA's explicit alignment with the ANC. However, there is a strong perception in the community that the forum works closely with the Democratic Alliance. Certainly it does have the ear of the Mayor and Premier. As Zille explains,

There is no community in Cape Town - not a single one - that has received the ongoing attention of the Mayor and myself, or the sheer commitment of resources, that Hangberg has. We have met with elected representatives of the community at least 30 times in scheduled and unscheduled engagements (and at least 300 days have been consumed by ongoing mediation and facilitation)...and we have a dedicated task team of personnel from the City and the Province to detect and monitor the progress of implementing the 'Peace and Mediation Accord'.(Zille, 2014)

It is difficult to conclude whether the formation and operation of the PMF have directly linked to the strengthening of the Democratic Alliance electorally, not least because voting is by secret ballot. Voting in Hangberg is in fact very changeable, as the graphs in Figure 1 demonstrate. The Democratic Alliance had increasing support prior to the 'Battle of Hangberg' in 2010, after which, unsurprisingly, support declined in favour of the ANC. More recently, in 2016 municipal elections, support for the Democratic Alliance again increased. Based on interviews with PMF leaders it seems working with the PMF may demonstrate an effective political strategy for people in a community which felt abandoned or disenchanted with the ANC. As noted above, current leaders of the PMF, such as Craig and Eunice, were active in the ANC-aligned HBCA prior to the formation of the PMF. This suggests that changing political allegiance may be seen as an effective way of generating development in the community, even if the resources accessed are unevenly allocated.

It is important to note that different elections (municipal/ provincial/ national) mean different things to different voters and are approached as such. People may vote on the basis of the promise of delivery of a fairly specific local good on one level, but may "vote [with] their conscience" on another level' (Gay, 1998:15-16). This may be what the changing nature of party support in Hangberg demonstrates. Clients appreciate the different ways the state works and thus may respond differently at different times. 'The appreciation of the different functions of various levels...suggests that clientelism is not an all-embracing, imposed from above world view but a strategy that is both selectively employed and the product of a sophisticated and reasoned grasp of the political process as a whole' (Gay, 1998: 16). The idea that clientelism is an effective mechanism for electoral mobilisation is misleading. Patrons, brokers and 'clients' are involved in on-going problem-solving, involving intricate webs of material and symbolic resources (Auyero, 1999: 301). 


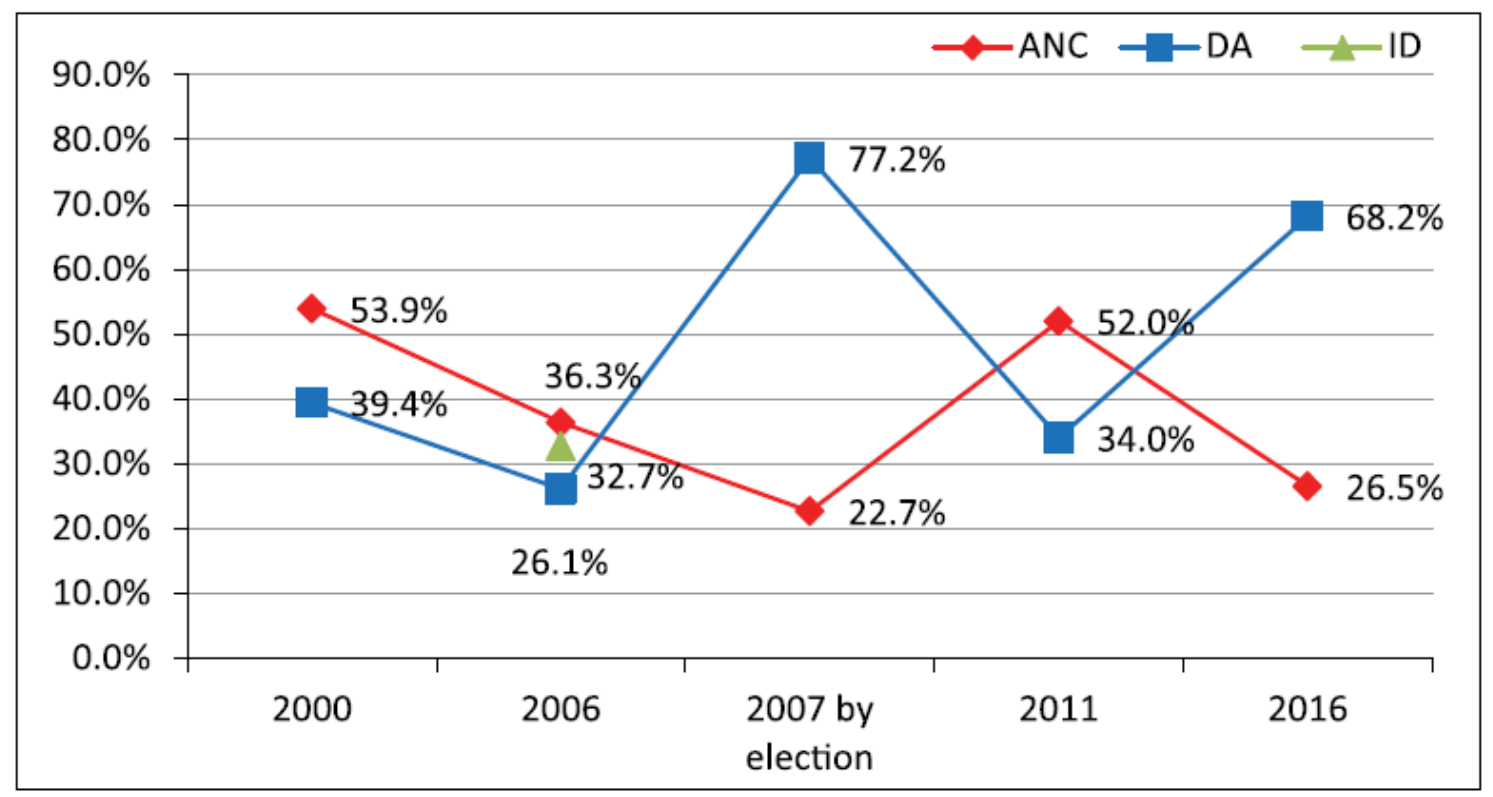

Figure I. Hangberg municipal election results 2000-2016.

It is clear that clientelism relates not only to a political actor gaining votes in return for goods and services; it can also include 'a more implicit but nonetheless firm understanding between public administration and whole regions that it takes a certain amount of government activity to produce votes' (Gay, 1998: 22). This is certainly relevant to the case in Hangberg, where the ruling Democratic Alliance undoubtedly recognises that it requires some level of acceptable development to attract political support. As illustrated above, the PMF can be understood as engaged in clientelistic relationships, particularly in light of broader understandings of clientelism emerging from the literature in South America, India and South Africa. However, the PMF also fulfils the role of a conventional civil society organisation. If an organisational structure can be both clientelistic and a part of liberal understanding of 'the good society', what does that tell us about the relationship between clientelism and democracy?

\section{Civil society, clientelism and democracy}

As discussed above, civil society is seen to hold the potential to play an important role in extending democracy. The question then is, can this role be extended to the concept and practices of clientelism? To investigate the relationship between clientelism and democracy I will look at the relationship between civil society and democracy and, drawing on empirical evidence from Hangberg, examine whether parallels can be drawn with the practices of clientelism. The analysis will first address the positive relationship between civil society and democracy and then look at how civil society might weaken democracy.

In the liberal framework, civil society is the space between the public and private spheres where civic action can take place and, as such, is a precondition for democracy (Chandhoke, 2001). Once this space exists and organisations are free from persecution they can then embark on the activities attributed to civil society by liberals - such as holding the state 
accountable, promoting civility and giving a 'voice' to the poor and marginalised. In a similar vein clientelism operates largely in a space between family and state; brokers are often neither family, nor government employees, but an intermediary functioning between the sphere of the personal and the bureaucratic. A political broker can 'either obstruct or facilitate the flow of demands, favours, good and services to or from some constituency' (cited in Auyero, 1999: 304). The PMF, for example, operates in this 'space' between public and private. It is both a civil society organisation and a clientelistic broker.

Once established, civil society can check, monitor and restrain the exercise of power by formally democratic states. Civil society can hold government accountable to the law and public expectations of responsible governance, monitor the performance of government bodies and assess the performance of individual politicians and government administrators (Diamond, 1999; White, 2004). For those in control in the state to be under pressure to use their power more responsibly and thus act accountably, civil society must provide a substantial 'balance of power'. Civil society thus strengthens democracy where it forms a countervailing power allowing for a 'balanced opposition' between state and society (White, 2004: 13-14). A further important aspect to strengthening accountability is that of increasing government responsiveness. Accountability is strengthened when government personnel, resources and performances change in response to binding collective consultation with subjects (Tilly, 2003).

Clientelism has not traditionally been seen as engendering accountability but, rather, as reinforcing power relations. Political scientists in particular see it as replacing political accountability with a transaction, where citizens 'surrender their vote for the right price' (Kitschelt and Wilkinson, 2007: 2). However, evidence from anthropologists and researchers who work at a local level have indicated that clientelism can stimulate accountability. As Gay (1998: 14) noted, clientelistic politicians and community leaders who do not deliver on a consistent basis soon lose support and are replaced by others. Piliavsky (2014: 34), talking of India, explained that "The people cast their chiefs... elders and MPs in the role of "patrons", not only entitling them to special honours and privileges but making them responsible - obliging them to provide, protect and stand accountable for their actions'. In South Africa research has shown that in certain contexts clientelism allows for local and immediate accountability of politicians to residents (Bénit-Gbaffou, 2011) and that patronage politics at the local level is often used as a deliberate political strategy, particularly where the state is seen as absent or indifferent (Dawson, 2014).

Clientelism is voluntary and transactional and, as a result, leads to an unstable relationship between political elites and masses. It can arguably foster substantive uncertainty which in turn leads to the for potential greater government responsiveness. Clientelism can also make principle-agent relations bi-directional (Fox, 2012) perhaps in a way that engenders more direct responsiveness than conventional civil society actions, as it is often difficult to link government policy change to direct civil society action, for example. Civil society does also try to generate party political support. Trade unions are a primary 
example; a ruling party may give concessions to unions - a listening ear in return for political support in the form of votes.

In Hangberg the PMF acts as a mediator to hold the state to developmental promises; as with other types of civil society organisations it ensures some level of accountability by keeping politicians and administrators 'on their toes'. The evidence for this is the numerous meetings the Mayor and Premier have had with the PMF, arguably more access than any other community in Cape Town (Zille, 2014). The PMF is also held accountable by its clients who have demonstrated that they will change allegiance if the forum is unable to offer resources or opportunities. According to a member of the Hout Bay ratepayers association, as well as a current HBCA member, there has been growing support in Hangberg for the HBCA, who are supported by the ANC. The ANC national government are responsible for the allocation of fishing rights and the maintenance and upgrading of harbours; residents of Hangberg recognise that aligning with the HBCA may get them more access to economic opportunities and are clear that their affiliations can shift. As the leader of a women's movement in Hangberg explained 'I am not going to bite the hand that feeds me, if national works better I will go with them'. Clientelism then, as with civil society, can strengthen accountability and responsiveness.

A further democratic role civil society can play is to nurture traditions of civic engagement. Civil society can foster civic engagement through building social capital (features of social organisations such as networks, norms and social trust that facilitate coordination and cooperation for mutual benefit). In turn, civic engagement can affect the performance of representative government (Putman, 1998). This is linked to the liberal attribute of civil society organisations as 'schools for democracy': this was de Tocqueville's view of civic associations in America, where they instilled habits of civic virtue and public spirit into their members (Blaug and Schwarzmantel, 1988: 477).

Clientelistic bonds have traditionally been seen as vertical in orientation, and therefore the opposite of horizontal networks of civic engagement that are the true roots of a civic community and which in turn 'make democracy work' (Putnam cited in Auyero, 1999: 298). However, there is increasing evidence to support the idea that clientelism is a form of civic engagement that does just what civil society organisations do, when engaging in democratic participation. Indeed, Gay argued that those who have made use of clientelism have 'articulated new demands, established alternative discursive arenas, challenged dominant practices and achieved, at the very least, a measure of symbolic power' (Gay 1998: 17). Auyero's (1999) work on political clientelism in Latin America describes complex social networks formed directly through patronage brokers. In Hangberg the PMF has performed similar tasks of building social capital. It has built networks across civil society by linking into multiple forums in Hout Bay, including, according to the Hout Bay Partnership project manager, forming a close relationship with their potentially influential and Provincially supported Partnership organisation. It has also built social networks (mainly of beneficiaries) in Hangberg through acting as an advice office and dispensing social and economic opportunities. These networks may be biased in favour of their participants' needs, 
but this does not differ significantly from other civil society organisations such as trade unions, which explicitly support member's interests.

Linked to the idea of civic engagement and responsiveness is that of participation. Democracy is strengthened when civil society increases possibilities for citizen participation and so opens up more effective channels of communication and negotiation between the state and citizens (Cornwall and Coelho, 2007). This in turn creates more opportunities for citizens to hold their government to account and to generate appropriate responses. Participation is seen as giving people representation and representation is a key element in empowerment. Empowerment in turn provides for 'a significant voice in public policy decisions' which, it is claimed, will then 'reduce poverty and enhance equity among all groups' (Blair cited in Gaventa, 2004: 32). Civil society can help citizens develop a stronger sense of their own right to claim rights or express opinions and so function more effectively in participatory processes and as government watchdogs. Through strengthening participation civil society increases the possibilities of access to the political system (through both ad hoc channels and institutions) and brings about a pluralisation of the ways in which political decisions are taken (Della Porta and Diani, 1999).

Clientelism holds the potential to include a form of participatory consultation. Patronage brokers, acting as mediators between the politician or state and citizen, can inform those in power of the needs of their clients, and potentially generate responsiveness. As Piper and von Lieres (2014: 5) argued, intermediaries who 'speak for' various groups of citizens can secure democratic outcomes, turning 'subjects into citizens' as it were, by 'explicitly teaching people about their rights in the democratic political system, and organising and mobilising on this basis'. Conventional forms of public participation (as exemplified in the Porto Allegra process) may be institutionalised, open to all and based on a set of predictable rules, but even processes such as these are vulnerable to the politicization of the application of rules. This, as Fox (2012) noted, suggests the existence of an important grey area that is neither clientelistic nor strictly rule based. Clients may also favour participation through their broker of choice in response to what is often seen as distrustful formal institutions, bureaucratic indifference and exclusion (Gay, 1998). Indeed, for, it is not necessarily the patron who establishes the relationship with possible clients or supporters; instead agency may equally lie with clients or residents in seeking out a patron who will give a specific group leverage and access to resources' (Dawson, 2014: 539). Choosing a clientelistic broker through which to engage politicians or the state reinforces the idea that 'democratic representation is both a mode of political authorisation and a social relation through which governance is organised' (Piliavsky, 2014: 31). Certainly in Hangberg the PMF acts as a channel of representation for many residents. Regular meetings with the leader of the party ruling the Province, and government departments, shows that the PMF was able to create an effective platform for participation which in turn holds as much potential to empower its 'clients' as other forms of civil society. The PMF may not represent all views in Hangberg, but arguably as representative as any other state-led participatory process. 
The role civil society can play as a democratic space, engendering accountability and responsiveness, creating social capital and civic engagement and opening opportunities for participatory democracy, is to variable extents comparable to the role clientelism plays. This is demonstrated by the existing practices of a civil society/clientelistic broker in the local community of Hangberg. In this sense clientelism can hold the potential, as much as civil society does, to strengthen democracy. For Piliavsky, 'good' patronage can 'provide a model for how democratic politics ought to work' (Piliavsky, 2014: 27).

\section{Civil society, clientelism and the weakening of democracy}

The assumption that civil society necessarily promotes democratisation has been consistently critiqued. For some, the role of civil society in democratisation is far more complex than the liberal democratic model implies (Mercer, 2002). In the Gramscian tradition, civil society theorists would argue that the liberal perspective does not pay sufficient attention to the question of power and to the internal dynamics of civil society itself. Civil society is not automatically inclusive; unequal economic, social and cultural resources can shape the contours of civil society. Civil society can be factional and have particular interests and thus be a source of great inequality and coercion. Civil society is an innately pluralist space filled with myriad groupings. Even with convergence around the pluralism and the dispersion of interests and social forces in civil society, the pluralist character of civil society still neither ensures democracy nor implies a strengthening of the open domain of public life (Roniger, 1994). For example, Fatton noted that, 'embedded in the coercive social discipline of the market, civil society is virtually bound to come to the defence and promotion of private rights and sectional claims' (Fatton, 1995: 71). This may result in a scenario where not everyone can participate equally.

Earlier writing on clientelism frequently saw the clientelistic relationship as one of domination and inequality, including different forms of social interaction such as exchange, conflict and prostitution. Clientelistic relations constituted a realm of submission (see Auyero, 1999). Certainly clientelism thrives in situations of inequality and poverty (Gay, 1998) and as such is poorly suited to challenging entrenched social or economic inequality and hegemonic positions of power. This is demonstrated by patronising comments made by Zille (2014), the Premier of the Western Cape in relation to development in Hangberg. 'Had the community worked together with the City and the Province and stuck to negotiated agreements' - in other words, done what we wanted - progress would have been faster. Zille attributes problems in Hangberg to the idea that for the community it is

...easier to remain marginalised and reinforce the perception of victimhood, than it is to seize the extraordinary opportunities and take responsibility for the development and transformation of their community...The Mayor and I have often been tempted to withdraw from the Hangberg process altogether, and concentrate on communities more amenable to co-operative development. (Zille, 2014)

Clientelistic practices struggle to challenge existing power holders who can quickly remove their patronage. 
Furthermore, clientelism will struggle to challenge the neo-liberal logic of the state. As Beresford (2015) explained, clients may have short-term agency where they align with an effective local patron, but this reflects a strategy of navigating dependency rather than engaging in transformative forms of political agency. This, however, is no different from the obstacles that civil society organisations face. Clientelism can lead to the subordination of the masses to political elites and limit the role of the clients to challenge power. It may also inhibit collective organisation, reducing social movement's agency to push for wider policy change, and fragment the poor (Bénit-Gbaffou, 2011; Gay, 1998). Certainly in Hangberg the PMF's relationship with the City and Province has fragmented opposition to the City and weakened the position of those whose disagree with proposed developments. This has facilitated, to some extent, the completion of the USIP, but on the City's terms.

In line with the idea that civil society is the realm of the partial interest is the notion that civil society groups may weaken democracy where they do not follow democratic principles themselves (Bayart, 1986; Zuern, 2000). Civil society organisations may not be interested in, or motivated to build, a democratic culture. Civil society can be used for other purposes, including, for example, for economic ambitions, cultural or religious identity and ideology (Van Rooy, 1998). In practice civil society can hand control of resources to individuals and oligarchies who may limit democracy's reach. In a similar vein civil society activity can be relentlessly rent seeking, penetrating the state with a diversity and magnitude of demands. This can impose unsustainable fiscal obligations on the state and leave it little in the way of a truly public sector that is concerned for the overall welfare of society (Diamond, 1999). In clientelistic practices where patrons and brokers are individuals there may be a strong correlation with concerns of following undemocratic practices and partial interests. However, this may not always be the case, particularly where brokers are organisations, or there is collective clientelism. The PMF, for example, was formed through democratic elections in multiple sections of the community. Certainly there are complaints, as voiced by Pastor Bill and the leader of a women's network, that the elections were held in small venues with the result that many residents felt excluded from discussions because they could not see what was taking place from outside; or they implicitly felt unwanted. Yet, this is a concern that could face any civil society organisation. In general however, clientelism is not well suited to building democratic cultures within a clientelistic network.

Civil society can also weaken democracy where organisations try to act as a substitute for coherent political parties or try to crowd out democratic institutions (Diamond, 1999). On the one hand, interest groups cannot aggregate interests as broadly across social groups and political issues as political parties can; and on the other, impairing state institutions will harm political institutionalisation. In this view it is a strong democratic political system that is an end goal, not necessarily a strong civil society. In this context, on the surface clientelism could be seen as a threat to democracy. It is not a natural bedfellow with democratic institutions. However, clientelistic mediators (such as the PMF) often function as advice offices. In this role they direct their clients to the relevant government authorities to 
receive services due to them (such as which clinic to go to, or where to access state grants). In this way clientelism can strengthen political institutionalisation.

Looking at the aims, actions and internal dynamics of civil society organisations illustrates that it is by no means conclusive that civil society strengthens democracy through its mere existence. It can be a source of inequality and coercion, view itself as superior to the formal democratic realm, undermine the ability of the state to mediate conflict, advance nondemocratic principles, not practice internal democracy, propagate conflict or rent-seeking behaviour, or shy away from challenging state actions. Clientelism too can play these roles and hold the potential to undermine democracy. Yet, just as with civil society, clientelistic practices need to be investigated before these judgements are made.

\section{Conclusions}

This article offers an attempt to build on literature that frames everyday political practices in the global south as potentially democratic in their own right. Following Koelble and Lipuma it 'jettisons' the idea that progress must follow an idealised, essentialised modernity based on the Euro-American experience. Instead it is important to grasp how democracies in the global South create what their electorate understands democracy to be:

Rather than approach democracy from the standpoint of the Western model, the process needs to be reversed through a meticulous political anthropology of the ways in which the governed would like to be governed and the ways in which governance currently takes place. (Koelble and Lipuma, 2008: 21).

Much of the scholarship looking at the concept of civil society is derived from Western models of state-society engagement that often do not provide adequate templates for understanding associational life in complex, developing societies. While a view of civil society as structured, formalised organisations that perform transparent democratic tasks such as 'building schools of democracy' and 'acting as watchdogs of the state' may be valid, it must be supplemented by an idea of civil society that includes uninstitutionalised, hybrid social activities. Here civil society (or more appropriately 'associational life') takes account of the structure of society itself, power relations as well as underlying cultural values in local communities.

Concerns with limited understandings of civil society are voiced by a range of scholars who have spent time researching the real lived experiences of the citizens of the global South. Bayat, studying the Middle East, for example, noted that the 'focus on the notion of 'civil society' tends to belittle or totally ignore the vast arrays of often uninstitutionalised and hybrid social activities which have dominated urban politics in many developing countries' (Bayat, 1997). Chatterjee (2004) also challenged the uncritical notions of civil society, arguing that civil society in India is in reality relevant only to the educated elite and is separate from the popular classes or what he terms 'political society'. While Chatterjee's analysis may not fully translate to the South African context he stretches conventional norms 
of civil society in ways that deepen our understanding of associational life and its relationship to democracy. Africanists, too, argue that in order to define and understand the role of civil society it is necessary to take account of the structure of society itself. Civil society, understood as the basic rules of the game and processes of defining them, must be derived from underlying cultural values (Harbeson, 1994). Of significance in the context of this argument is that Western understandings of civil society would omit neo-patrimonial relations to the state (Kasfir, 2004: 121). The African perspective of civil society therefore emphasises the need to reconstitute understandings of civil society based on underlying cultural norms, values and political contexts, derived from an analysis of the lived reality of African citizens.

If civil society includes associational life in complex, often precarious, urban settings, how does it differ from clientelism, a practice long associated with poverty and inequality? In this view clientelism can be seen as a form of civil society; it may often materialise in unstructured ways keeping close to an associational view of civil society, but, as demonstrated by the PMF, it can also be structured and formalised. Where clientelism is formalised and understood as a 'legitimate' civil society organisation, its actions are no more, or less, democratic than when seen as a form of clientelism. Rethinking clientelism encourages a re-evaluation of the idea of neo-patrimonialism in Africa, and state-capture in South Africa. While both concepts undoubtedly refer to often deeply problematic practices of inequitable distribution of state resources, they too must be analysed with contextual understandings to investigate where the practices are not a reflection of weak democracy, but rather reflect difference conceptions of state-society engagement.

A key challenge to this framing is the important question of how a clientelistic organisation can be democratic if it reduces the agency of citizens to that of clients. This research does not demonstrate that clientelistic organisations are inherently democratic; rather, that they have potential to hold moments of democracy. Thus an organisation can be both clientelistic and perform democratic tasks. This reinforces the view that one should not uncritically assume clientelism is harmful to democracy; its practices need to be interrogated just as one would other civil society formations. Clientelism is not necessarily a reflection of imposed power relations, but can demonstrate a conscious political strategy on the part of its protagonists. Engaging in clientelism may be seen by some as an effective way of generating development in their community. As demonstrated, both civil society and clientelism can hold democratic and anti-democratic impulses. Democracy as a process is context dependent, not fixed in time and place.

\section{Funding}

The author(s) disclosed receipt of the following financial support for the research, authorship, and/or publication of this article: This work is based on the research supported in part by the National Research Foundation of South Africa for the grant, Unique Grant No. 106923. 


\section{Notes}

1. Citizenship here is broadly conceived of as the agency of people in respect of political authority (largely that of the state). It is used in a substantive sense rather than only referring to legal status.

2. While research on sensitive topics such as clientelism can be challenging, respondents in Hangberg were open and forthcoming with their views. However, all interviewees have been given different names in the text to protect their identity. Several interviews and focus groups were conducted with a research assistant who had previously resided in the area.

3. There are three broad 'communities' in Hout Bay: the Coloured area of Hangberg, the predominantly black township of Imizamo Yethu (with a population of over 30,000 residents) and the predominantly white area of the Valley (which occupies the largest land area in the ward). 'Coloured' is a varied, composite racial category that includes the descendants of relationships between white and black African people, the descendants of 'Malay' slaves brought from South-East Asia and descendants of the indigenous Khoi and San who lived in the Western Cape before the arrival of either white or black African people (Seekings, 2008: 3). 


\section{References}

Auyero J (1999) 'From the client's point(s) of view': How poor people perceive and evaluate political clientelism. Theory and Society 28(2): 297-334.

Bayat A (1997) Un-civil society: The politics of the 'informal people'. Third World Quarterly 18(1): 53-72.

Bayart J-F (1986) Civil society and the state. In: Chabal P (ed.) Political Domination in Africa: Reflections on the Limits of Power. Cambridge: Cambridge University Press.

Bénit-Gbaffou C (2011) 'Up close and personal' - How does local democracy help the poor access the state? Stories of accountability and clientelism in Johannesburg. Journal of Asian and African Studies 46(5): 453-464.

Beresford A (2015) Power, patronage, and gatekeeper politics in South Africa. African Affairs 114(455): 226-248.

Blaug R and Schwarzmantel J (1988) Democracy: A Reader. Edinburgh: Edinburgh University Press. Bratton M (1994) Civil society and political transitions. In: Harbeson J (ed.) Civil Society and the State in Africa. Boulder: Lynne Reinner Publishers, pp. 51-81.

Calland R (1998) State ethics and executive accountability. In: Wilmot J and Levy M (eds) Pulse Passages in Democracy Building: Assessing South Africa's Transition. Cape Town: Idasa, $62 \mathrm{pp}$.

Chandhoke N (1995) State and Civil Society: Explorations in Political Theory. New Delhi: Sage Publications. Chandhoke N (2001) The 'civil' and the 'political' in civil society. Democratization 8(2): 1-24.

Chatterjee P (2004) The Politics of the Governed: Popular Politics in Most of the World. New York: Columbia University Press.

Chipkin I (2016) The state, capture and revolution in contemporary South Africa. Working Paper. Johannesburg: Public Affairs Research Institute.

Cohen JL and Arato A (1994) Civil Society and Political Theory. Cambridge: The MIT Press.

Cornwall A and Coelho V (eds) (2007) Spaces for Change? The Politics of Citizen Participation in New Democratic Arenas. London: Zed Books.

Dawson H (2014) Patronage from below: Political unrest in an informal settlement in South Africa. African Affairs 113(453): 518-539.

De Lille P (2011a) We're making peace in Hangberg. Speech by Executive Mayor Patricia de Lille at the handover of 60 letters of commitment to residents currently occupying the City of Cape Town's properties in Hangberg. City of Cape Town. Available at: http://www.politicsweb.co.za/documents/were-making-peace-in-hangberg-de-lille (accessed 16 May 2017).

De Lille P (2011b) Speech by Executive Mayor Alderman Patricia De Lille on the Occasion of the Signing of the Hangberg Peace Accord. City of Cape Town. Available at: http://www.politicsweb.co.za/opinion/patricia-de-lille-on-the-hangberg-peaceaccord (accessed 16 May 2017)

Della Porta D and Diani M (1999) Social Movements: An Introduction. Oxford: Blackwell Publishers Ltd. de Sousa L (2008) Clientelism and the Quality(ies) of Democracy: Public and Policy Aspects. DISC Working Paper Series 2. Hungary: Centre for the Study of Imperfections in Democracy. 
de Tocqueville A (1959) Democracy in America. New York: Vintage Books.

de Wet P (2016) How to capture a state and escape. Mail and Guardian, 22 December.

Available at: http:// mg.co.za/article/2016-12-22-0o-how-to-capture-a-state-andescape (accessed 19 January 2017).

Diamond L (1994) Rethinking civil society: Towards democratic consolidation. Journal of Democracy 5(3): 4-17.

Diamond L (1999) Developing Democracy: Towards Consolidation. Baltimore: The Johns Hopkins University Press.

Edwards M (2004) Civil Society. Cambridge: Polity Press.

Ehebrecht D (2014) The challenge of informal settlement upgrading: Breaking new ground in Hangberg Cape Town? Master's Thesis, Universitätsverlag Potsdam, Potsdam.

Ekeh P (1975) Colonialism and the two publics in Africa: A theoretical statement. Comparative Studies in Society and History 17(1): 91-112.

Fatton R (1995) Africa in the age of democratization: The civic limitations of civil society. African Studies Review 38(2): 67-99.

Fieuw WVP (2011) Informal settlement upgrading in Cape Town's Hangberg: Local government, urban governance and the 'Right to the City'. Master of Philosophy, Stellenbosch University, Stellenbosch.

Fox J (2012) State power and clientelism: Eight propositions for discussion. In: Hilgers T (ed.) Clientelism in Everyday Latin America Politics. New York: Palgrave-MacMillan.

Gaventa J (2004) Towards participatory governance: Assessing the transformative possibilities. In: Hickey S and Mohan G (eds) Participation: From Tyranny to Transformation. London: Zed Books.

Gaventa J (2007) Forward. In: Cornwall A and Coelho V (eds) Spaces for Change? The Politics of Citizen Participation in New Democratic Arenas. London: Zed Books.

Gay R (1998) Rethinking clientelism: Demands, discourses and practices in contemporary Brazil. European Review of Latin American and Caribbean Studies 65: 7-24.

Greef K (2013) The booming illegal abalone Fishery in Hangberg: Tough lessons for smallscale fisheries governance in South Africa. Master of Science, University of Cape Town, Cape Town.

Harbeson J (ed.) (1994) Civil Society and the State in Africa. Boulder: Lynne Reinner.

Holston J (2008) Insurgent Citizenship: Disjunctions of Democracy and Modernity in Brazil. Princeton, NJ: Princeton University Press.

Kaganof A and Valley D (2010) The Uprising of Hangberg [Film Documentary]. Available at: https://www. youtube.com/watch?v=bRjMB3znA2E (accessed 1 May 2015).

Kasfir N (2004) Civil society, the state and democracy in Africa. In: Burnell P and Calvert P (eds) Civil Society in Democratization. London: Frank Cass, pp. 117-142.

Kitschelt $\mathrm{H}$ and Wilkinson S (eds) (2007) Patrons, Clients, and Policies: Patterns of Accountability and Political Competition. Cambridge: Cambridge University Press, pp. 1-49.

Koelble $\mathrm{T}$ and Lipuma E (2008) Democratizing democracy: A postcolonial critique of conventional approaches to the 'measurement of democracy'. Democratization 15(1): $1-28$. 
Kumar K (1993) Civil society: An inquiry into the usefulness of an historical term. The British Journal of Sociology 44(3): 375-395.

Lodge T (2014) Neo-patrimonial politics in the ANC. African Affairs 113(450): 1-23.

Medard JF (1982) The underdeveloped state in tropical Africa: Political clientelism and neopatrimonialism. In: Clapham C (ed.) Private Patronage and Public Power. London: Pinter, pp. 162-189.

Mercer C (2002) NGOs, civil society and democratization: A critical review of the literature. Progress in Development Studies 2(1): 5-22.

Misselhorn M (2008) Position Paper on Informal Settlements Upgrading. KwaZulu-Natal: Project Preparation Trust. Available at: http://www.pptrust.org.za/wpcontent/uploads/delightful-downloads/informal-settlement-paper.pdf (accessed 10 September 2015).

Piliavsky A (ed.) (2014) Patronage as Politics in South Asia. Cambridge: Cambridge University Press.

Piper L and von Lieres B (2014) Introduction: The crucial role of mediators in relations between states and citizens. In: Von Lieres B and Piper L (eds) Mediated Citizenship: The Informal Politics of Speaking for Citizens in the Global South. Oxford: PalgraveMacmillian, pp. 1-22.

Pitcher A, Moran MH and Johnston M (2009) Rethinking patrimonialsm and neopatrimonialism in Africa. African Studies Review 52(1): 125-156.

Pratt B (ed.) (2003) Changing Expectations? The Concept and Practice of Civil Society in International Development. Oxford: INTRAC.

Putman R (1998) Bowling alone: America's declining social capital. In: Diamond L and Plattner M (eds) The Global Resurgence of Democracy, 2nd ed. Baltimore, $\mathrm{OH}$ : Johns Hopkins University Press, pp. 290-306.

Roniger L (1994) Civil society, patronage and democracy. International Journal of Comparative Sociology 35(3/4): 207-220.

Roniger L (2004) Political clientelism, democracy, and market economy. Comparative Politics 36(3): 353-375.

South African Press Association (2010) SAN Parks now a respondent in Hangberg case. Times Live, 18 October. Available at: http://www.timeslive.co.za/local/2010/10/18/sanparks-now-respondent-in-hangberg-case\# (accessed 30 September 2015).

Seekings J (2008) The continuing salience of race: Discrimination and diversity in South Africa. Journal of Contemporary African Studies 26(1): 1-26.

Shawstack Sassoon S (2000) Gramsci and Contemporary Politics: Beyond Pessimism of the Intellect. London: Routledge.

Simon R (1991) Gramsci's Political Thought: An Introduction. London: Lawrence and Wishart.

Tilly C (2003) When do (and don't) social movements promote democratization? In: Ibarra P (ed.) Social Movements and Democracy. New York: Palgrave Macmillan, pp. 2146.

Van Holdt K (2013) South Africa: The transition to violent democracy. Review of African Political Economy 40(138): 589-604 
Van Rooy A (1998) Civil Society and the Aid Industry: The Politics and Promise. London: Earthscan. White F (2008) Strengthening democracy? The role of social movements as agents of civil society in post-apartheid South Africa. PhD Thesis, University of London, UK.

White G (2004) Civil society, democratization and development: Clearing the analytical ground. In: Burnell P and Calvert P (eds) Civil Society in Democratization. London: Frank Cass, pp. 6-21.

World Bank (2000) Anticorruption in transition: A contribution to the policy debate. Washington: World Bank. Available at: http://documents.worldbank.org/curated/en/825161468029662026/Anticorruptionin-transition-a-contribution-to-the-policy-debate.

Young C (1994) In search of civil society. In: Harbeson J (ed.) Civil Society and the State in Africa. Boulder, CO: Lynne Reinner Publishers.

Zille H (2014) SA Today: The salutary story of Hangberg. Bokamoso News, March 23. Available at: https:// www.da.org.za/2014/o3/sa-today-the-salutary-story-ofhangberg/ (accessed 15 July 2015).

Zuern E (2000) The changing roles of civil society. In: Liebenberg I and Solomon H (eds) Consolidation of Democracy in Africa: A View from the South. Aldershot: Ashgate. 